\title{
Promosi Kesehatan Mental Menggunakan Media Sosial (Instagram) Bagi Kalangan Remaja Di Masa Pandemi Covid-19
}

\author{
Muhammad Ibnu Aksol M, Muhammad Ali Sodik \\ IIK STRADA Indonesia \\ akslibnu@gmail.com, alisodik2012@gmail.com
}

\begin{abstract}
Abstrak
Sejak akhir 2019, pandemi Covid-19 dialami oleh berbagai negara termasuk di Indonesia. Langkah-langkah pencegahan penyebaran pandemi Covid-19 berdampak pada adanya pembatasan aktivitas fisik serta kebijak penyelenggaraan Pembelajaran Jarak Jauh (PJJ) bagi siswa mulai dari jenjang sekolah dasar sampai perguruan tinggi. Tujuan penelitian ini adalah mendapatkan gambaran kesehatan mental remaja selama pandemi Covid-19 dan peran faktorfaktor sosiodemografi dalam memengaruhi kesehatan mental remaja. Kesehatan jiwa terdiri dari beberapa jenis kondisi yang secara umum dikategorikan dalam kondisi sehat, gangguan kecemasan, stres dan depresi. Hal tersebut dikarenakan terdapat beberapa factor dan tantangan selama pembelajaran. Kondisi inilah yang mengakibatkan timbulnya konflik batin dan tekanan yang di rasakan para remaja sehingga mengganggu kesehatan mental mereka. Data menunjukkan bahwa penggunaan media digital khususnya media sosial (Instagram) semakin meningkat, terutama semenjak pandemi Covid- 19, khususnya di kalangan remaja. Selain itu, berbagai studi juga telah memperlihatkan keterkaitan antara penggunaan media digital dan kesehatan mental remaja. Dengan demikian, promosi kesehatan dengan memanfaatkan media digital khususnya melalui aplokasi Intagram akan berperan penting dalam mengelola kesehatan mental remaja.
\end{abstract}

Kata kunci: Covid 19, Remaja, Kesehatan Mental, Media sosial

\begin{abstract}
Since the end of 2019, the Covid-19 pandemic has been experienced by various countries, including Indonesia. Measures to prevent the spread of the Covid-19 pandemic have an impact on the limitation of physical activity as well as the policy of implementing Distance Learning (PJJ) for students from elementary school to university. The purpose of this study was to obtain an overview of adolescent mental health during the Covid-19 pandemic and the role of sociodemographic factors in influencing adolescent mental health. Mental health consists of several types of conditions that are generally categorized into healthy conditions, anxiety disorders, stress and depression. This is because there are several factors and challenges during learning. This condition results in the emergence of inner conflicts and pressures felt by teenagers so that it interferes with their mental health. Data shows that the use of digital media, especially social media (Instagram) is increasing, especially since the Covid-19 pandemic, especially among teenagers. In addition, various studies have also shown a link between the use of digital media and adolescent mental health. Thus, health promotion by utilizing digital media, especially through the application of Instagram, will play an important role in managing adolescent mental health.
\end{abstract}




\section{Latar Belakang}

Pandemi Covid-19 terjadi secara menyeluruh di berbagai negara. Covid-19 merupakan penyakit menular yang disebabkan oleh virus corona yang baru ditemukan pada akhir 2019. Sebagian besar orang yang terinfeksi virus corona akan mengalami penyakit pernapasan ringan hingga sedang dan sembuh tanpa memerlukan perawatan khusus. Covid-19 pertama kali dikonfirmasi di kota Wuhan, Cina pada 31 Desember 2019. kemudian menyebar ke berbagai negara hingga pada tanggal 11 Maret 2020, Organisasi Kesehatan Dunia (WHO) menetapkan Covid-19 dalam kategori Pandemi (WHO, 2020). Penyebaran Covid-19 juga terjadi di Indonesia, dengan kasus pertama pada tanggal 1 Maret 2020. Kasus Covid-19 di Indonesia sendiri mengalami peningkatan yang cukup signifikan. Dari data pada 30 Juni 2020, jumlah kasus terkonfirmasi di Indonesia adalah 56.385 kasus dengan jumlah kematian mencapai 2.876 (Gugus Tugas Percepatan Penanganan Covid-19). Berbagai upaya dilakukan untuk menekan penyebaran Covid-19. WHO menghimbau penerapan beberapa protokol kesehatan yang cukup ketat seperti menggunakan masker, mencuci tangan dan pembatasan sosial dan aktivitas fisik. Di beberapa negara seperti Cina, Italia, Spanyol, Malaysia dan Filipina menerapkan sistem Lockdown. Negara-negara tersebut menutup akses masuk maupun keluar dari negara tersebut. Sedangkan di Indonesia pemberlakuan protokol kesehatan dimulai sejak pertengahan Maret 2020. Selain itu, Pemerintah melalui Kementerian Pendidikan dan Kebudayaan juga mengumumkan bahwa kegiatan belajar mengajar di sekolah ditutup, serta menetapkan pembelajaran melalui media daring. Berbagai penelitian menunjukkan bahwa wabah penyakit seperti wabah SARS pada 2003, H1N1 pada 2009 dan Ebola pada tahun 2014 dapat memengaruhi kesehatan mental. Dampak psikologis yang dikaitkan dengan wabah penyakit diantaranya adalah depresi (Ko, Yen, Yen, \& Yang, 2006), stress dan kecemasan (Taha, Matheson, \& Anisman, 2014), serta gangguan stress pasca-trauma (Shultz, Baingana, \& Neria, 2015). Permasalahan psikologis yang terjadi sebagai dampak dari bencana terkait kesehatan tidak hanya berdampak pada orang dewasa, tetapi juga pada anak-anak dan remaja. Berbagai bentuk gangguan yang muncul sebagai dampak dari menghadapi pandemi yang disebutkan diatas termasuk pada permasalahan distress psikologis dan disfungsi sosial. Distress psikologis sendiri didefinisikan sebagai keadaan emosional yang ditandai dengan depresi (kehilangan minat, kesedihan dan keputusasaan) dan gejala kecemasan (tegang dan gelisah). Penelitian mengenai dampak pandemi Covid-19 terhadap kesehatan mental telah dilakukan di beberapa negara dengan metode daring melalui Form yang disebar pada media sosial atau pada platform survey online. Adanya pembatasan sosial dan aktivitas fisik serta ditutupnya sekolah bagi remaja menjadi faktor yang dapat memengaruhi kesehatan mental remaja. Kesehatan Mental didefinisikan sebagai suatu keadaan kesejahteraan dimana individu menyadari kemampuannya sendiri, dapat mengatasi tekanan hidup yang normal, dapat bekerja secara produktif dan bermanfaat serta mampu memberikan kontribusi ke komunitasnya. Kesehatan mental penting bagi remaja terutama berhubungan dengan kurangnya kualitas 
tidur, kesulitan fokus, sering lupa dan dapat membuat remaja demotivasi dalam belajar sehingga menjadikan belajar kurang. Penelitian ini bertujuan untuk memberikan edukasi melalui promosi kesehatan menggunakan media sosial yaitu Instagram karena media tersebuat banyak diakses oleh banyak orang terutama kalangan remaja yang pada masa sekarang ini rentan mengalami stres terutama di era pandemi Covid 19 ini. Banyaknya kegiatan yang dibatasi dengan berbagai aturan pemerintah yang ketat sehingga banyaknya remaja yang merasa tertekan dan rawan mengalami stres dan ketakutan akan pandemi Covid 19 yang menyebar cukup cepat.

\section{Masalah}

Ditutupnya sekolah dan dibatalkannya berbagai aktivitas penting, banyak remaja kehilangan beberapa momen besar di kehidupan mereka - dan juga momen keseharian seperti mengobrol dengan teman dan berpartisipasi di sekolahnya. Para remaja menghadapi situasi baru ini bukan tidak hanya dengan kecewa, namun juga kecemasan dan perasaan terisolasi yang membebani, terhadap perubahan hidup akibat wabah yang secara cepat. Saat kesehatan mental remaja tertekan, bisa dilihat tanda-tandanya seperti terlihat tidak bersemangat, nafsu makannya berkurang, pola tidurnya terganggu/susah tidur, dan juga khawatir yang berlebihan. Hal imi dikarenakan kurangnya edukasi pada para remaja mengenai informasi yang beredar di masa pandemi ini sehingga menyebabkan gangguan kesehatan mental terutama stres.

\section{Tinjauan pustaka}

Kesehatan mental adalah suatu hal yang sangatlah penting. Kesehatan mental juga merupakan salah satu faktor yang berpengaruh terhadap kesehatan jasmani kita. Pengertian dari kesehatan mental ada bermacam-macam tergantung dari sudut pandang ahlinya, antara lain: 1) Kesehatan mental yaitu dimana seseorang terbebas dari gelaja penyakit atau gangguan kejiwaan,

2) Kesehatan mental adalah wujud dari keharmonisan antara fungsi-fungsi jiwa. Untuk mengukur kesehatan mental sendiri tidaklah mudah, tidak seperti mendeteksi penyakit pada biasanya. Dampak dari pandemi pada kesehatan remaja antara lain yaitu Dampak psikis

- Pada dasarnya remaja adalah masa-masa perubahan di mana remaja banyak mengalami rasa cemas, stress, takut, dan mood swing. Bahkan sebelum pandemi.

- Pandemi menambah intensitas stress saat masa peralihan remaja ini.

- Pada saat pandemi, kecemasan dan depresi meningkat pada remaja.

- Pandemi memaksa remaja untuk dijauhkan dari interaksi sosial, fisik, dan edukasi yang normal.

- Remaja jadi banyak berinteraksi lewat online, termasuk media sosial dan game online.

- Remaja terisolasi dengan dunia luar dan teman-temannya. Sementara mereka juga harus di rumah terus karena menghindari virus.

-masalah mental pada remaja saat pandemi

1. stres

Reaksi tubuh terhadap perubahan yang memerlukan respon atau adaptasi. Tubuh bereaksi terhadap perubahan tersebut secara fisik, mental, dan emosional. Kita 
bisa merasakan stres dari lingkungan, tubuh, atau pikiran kita sendiri.

\section{2. depresi}

Suatu gangguan yang ditandai dengan suasana hati yang terus tertekan dan membuat kehilangan minat pada aktivitas yang biasanya dilakukan sehingga kualitas hidup menurun secara signifikan.

\section{3. anxiety}

Gangguan kesehatan mental yang ditandai dengan perasaan khawatir, cemas, atau takut yang cukup kuat untuk mengganggu aktivitas sehari-hari.

Strategi sehat mental untuk remaja :

1. Strategi self-care

- Menjaga tubuh

- Tidurcukup

- Melakukanolahragarutin

- Makansehat

- Hindarirokok,narkoba,alkohol

- Batasilihatsocialmedia

- Bersantaidanberistirahat

Menjaga pikiran

- Tetapmelakukanrutinitas

- Batasibacaberita

- Tetapusahakansibuk

- Fokuspadahalyangpositif

- Lakukankegiatanmeningkatkan spiritual

- Tentukan prioritas dan goal kecil tiap hari

Terhubung dengan orang lain

- Koneksi virtual: zoom, video call, telepon, chat
- Lakukan sesuatu untuk orang lain

- Dukung teman atau keluarga yang membutuhkan

Artikel ini dibuat untuk mengatasi permasalahan kesehatan mental terutama pada remaja yang pada masa sekarang ini banyak kegiatan-kegiatan yang dilakukan secara daring baik sekolah,kuliah, dan apapun kegiatan yang berhubungan dengan suasana ramai terus dibatasi dan dipeketat oleh pemerintah. Dampak dari hal tersebut yaitu banyaknya remaja yang mengakses hiburan atau bertemu sapa dengan temantemannya melalui media digital yaitu media sosial terutama Instagram untuk menghibur diri mereka pada era pandemi ini, disamping itu dengan diaksesnya media sosial Instagram ini memberikan dampak yang positif hingga dampak yang negatif, dampak positif penggunaan media sosial ini antara lain kita dapat terhubung dengan teman kita yang jauh waupun dalam keadaan pandemi. Dan dampak negatif dari media sosial ini yaitu kita menjadi jarang berinteraksi dengan orang dirumah kita karena terlalu terfokus kepada media sosial. Oleh karena itu mengenai kasusu tersebut artikel ini bertujuan untuk memberikan promosi kesehatan atau edukasi kesehatan mental melalui platform intagram ini karena aplikasi ini banyak diakses terutama oleh para remaja sehinggah dengan adanya edukasi kesehatan mental ini dapat membantu para remaja dalam menyeimbangkan antara media sosial dan interaksi sosial agar tidak mudah stres dan cemas karena di era pandemi ini banyak keadaan yang berubah terutama pada kegiatan sehari-hari.

\section{Pembahasan}

Di era pandemi wabah COVID-19

sekarang kita dituntut untuk bekerja 
maupun menjalani kegiatan akdemik seperti sekolah dan perkuliahan dari rumah, walau sebagian besar individu juga terpaksa mau tidak mau harus bekerja secara langsung seperti biasa. Mengutip salah satu isi dari buku Menulis di Kala Badai Covid-19 yang disunting oleh Prof. Dr. Drs. Ersis Warmansyah Abbas, BA, M.Pd. dan Ibu Neka Erlyani, S.Psi, M.Psi., bahwa pandemi wabah COVID-19 tidak hanya menyerang fisik tetapi juga menyerang psikis. Terutamanya sebagai mahasiswa, tuntutan tugas akademik ada saja saatnya terasa berat oleh mahasiswa. Bisa jadi dirasa tugas tersebut ada di luar batas kemampuan sang mahasiswa dan menambah stres bukan malah membantu menjaga kesehatan mental. Tidak hanya tugas akademik, faktor lain yaitu terbatasnya kegiatan bersosialisasi yang dijalani sekarang juga turut andil dalam hal kesehatan mental maupun psikis. Dengan bercengkrama, sharing, atau bersendagurau bersama teman maupun bermacam individu lain memungkinkan kita untuk mendapat tambahan energi positif, insight, serta motivasi dalam diri yang mana bisa membantu dalam hal menjaga kesehatan mental.

Salah satu hal yang dapat dilakukan untuk menjaga kesehatan mental di masa pandemi yaitu dengan melakukan penyesuaian diri dengan apa yang terjadi di lingkungan sekarang. Penyesuaian diri perlu dilakukan untuk mendapatkan keharmonisan dan keselarasan antara tuntutan lingkungan dengan tuntutan di dalam diri. Yang mana bahwa seseorang harus menerima hal-hal ketika ia tidak mempunyai kontrol akan keadaan. Penyesuaian diri yang baik diukur dari seberapa baik seseorang mengatasi setiap perubahan yang terjadi dalam hidupnya. Penyesuaian diri adalah aspek mental penting dan sangat berkaitan dengan keyakinan seseorang terhadap kemampuan diri dalam mengendalikan berbagai rintangan dan menggunakan potensi diri. Dalam menyesuaikan diri terhadap lingkungan, masalah, maupun hal-hal baru diperlukan sebuah proses serta usaha dan apabila kita gagal dalam menyesuaikan diri tentu saja dapat menimbulkan kesehatan mental yang terganggu dan berujung pada stres.

Menjaga kesehatan mental dengan cara melakukan penyesuaian diri bisa diawali oleh menumbuhkan mindset dan motivasi. Di masa pandemi sekarang mahasiswa dihadapkan dengan yang namanya kuliah daring. Namanya saja daring, jelaslah suasana yang sangat berbeda dari kuliah biasanya dimana kita bisa mendengarkan materi secara langsung dan bertatap muka dengan dosen pemateri. Suasana yang berbeda itu pula dapat menimbulkan motivasi yang menurun. Walau terkesan lebih santai, kemungkinan timbulnya stres tetap saja tidak bisa diindahkan.

Pemahaman materi saat kuliah daring dirasa lebih lamban dan tidak sepenuhnya masuk ke memori serta pikiran. Belum lagi jikalau kita dihadapkan dengan kendala peliknya bermedia online seperti faktor device yang tidak memadai dan jaringan yang tidak stabil. Hal-hal seperti itulah yang menjadi faktor menurunnya mood serta motivasi berujung dengan kemungkinan pikiran negatif seperti menyalahkan diri sendiri, merasa bodoh, dan sebagai. Pikiran-pikiran tersebutlah yang dapat menimbulkan stres, namun kembali lagi dengan mindset di masingmasing individu. Kita harus berusaha menghindari perasaan dan pemikiran negatif tersebut, belajar menerima keadaan dan mengikuti arus 'jalani saja'. Aspek religiusitas juga sangat membantu dalam membangun mindset/motivasi dalam menghindari stres. 
Menjalani hobi sebagai escape dari kesibukan dan pemikiran sehari-hari yang menumpuk. Melakukan hobi membantu meningkatkan mood dan positivitas serta melepaskan tekanan stres. Menulis contohnya, tidak perlu menuangkan halhal yang berat dalam sebuah tulisan. Menulis bebas seperti menuangkan perasaan, menjabarkan sisi positif atau hal yang bisa disyukuri membantu kita untuk memupuk bahan bakar berupa energi positif. Menulis juga bisa berupa menulis di otak. Menulis di otak dalam arti menginput informasi melalui pancaindra, nyata ataupun abstrak, termasuk yang kita pikirkan, rasakan, bahkan "lamunkan" (game Abbas, 2020). Hobi lain seperti melukis, bermain, menyanyi, menari, berolahraga, dll. Namun ingat dalam menjalankan hobi dalam bentuk escape dari kesibukan janganlah berlebihan karena kita tetap harus fokus ke tujuan utama dan pencapaian yang kita sudah diatur. Beralih dari pengaruh yang ditumbuhkan diri sendiri, faktor lainnya yaitu lingkungansekitar. Sebisa mungkin hindarilah circle yang toxic. Lingkungan sekitar seperti ruang lingkup rumahkeluarga dan pertemanan mempengaruhi kesehatan mental tergantung dari cara kita berinteraksi dan respon akan satu sama lain serta bagaimana cara kita menerima serta memaknainya apakah akan menjadi positif atau negatif. Sekali lagi kembali ditekankan bahwa menjaga mental health adalah hal yang sangat penting. Kesehatan mental mempengaruhi kesehatan fisik. Kesehatan mental berpengaruh terhadap keputusan yang akan kita ambil, pastinya setiap keputusan berdampak apa yang akan terjadi kedepannya. Selain itu, kesehatan mental seorang individu juga memengaruhi suasana lingkungan sekitarnya. Kesehatan mental membantu kita untuk menggali potensi-potensi dan menjadi faktor produktivitas kita dalam menjalani sebuah pekerjaan.

\section{Kesimpulan}

Di masa pandemi yang serba sulit ini tidak hanya ketahanan fisik, tapi ketahanan psikis juga turut diuji. Kesehatan mental merupakan salah satu faktor utama yangmendukung kita supaya bisa melalui keadaan yang serba sulit ini. Dalam menjaga kesehatan mental kita bisa melakukan penyesuaian diri dengan cara mengatur pola pikir dan juga menumbuhkan motivasi. Selain itu berpegang teguh dengan aspek religiusitas juga sangat berpengaruh dalam meningkatkan pola pikir yang positif. Hal lainnya yaitu hobi. Hobi membantu kita untuk melepaskan stres. Selain dari diri sendiri, kondisi lingkungan dan orangorang sekitar juga menentukan kondisi mental health dan pendekatan edukasi melalui promosi kesehatan menggunakan media sosial sangat penting karena banyaknya remaja yang mengakses media sosial terutama instagram saat era pandemi ini memungkinkan sangat nermanfaat untuk menjadi pengingat mereka mengenai pentingnta kesehatan mental dan kondisi imun tubuh saat pandemi seperti sekarang ini.

\section{Daftar pustaka}

Bukhori, B. (2006). Kesehatan mental mahasiswa ditinjau dari religiusitas dan kebermaknaan

hidup. Psikologika: Jurnal Pemikiran dan Penelitian Psikologi, 11(22), 93-106

Ananda, S. S. D., \& Apsari, N. C. (2020). MENGATASI STRESS PADA REMAJA SAAT 
PANDEMI COVID-19 DENGAN

TEKNIK SELF TALK. Prosiding

Penelitian dan

Pengabdian kepada Masyarakat, 7(2), 248256.

Darmawanti, I. (2012). Hubungan antara tingkat religiusitas dengan kemampuan dalam

mengatasi stres (coping stress). Jurnal

Psikologi Teori dan Terapan, 2(2), 102107.

Sprang, G., \& Silman, M. (2013).

Posttraumatic stress disorder in parents and youth after health- related disasters. Disaster Medicine and Public Health Preparedness, 7(1), 105-110.

https://doi.org/10.1017/dmp.2013.22
Fitria, L., \& Ifdil, I. (2020). Kecemasan remaja pada masa pandemi Covid -19. Jurnal EDUCATIO: Jurnal Pendidikan Indonesia, 6(1), 1.

https://doi.org/10.29210/120202592

Verma, R., Balraha, Y., \& CS, G. (2011). Role of developmental and biological determinants. Ind Psychiatry J, 4-10. https://doi.org/10.4103/0972-6748.98407

Karina, Z., \& Sodik, M. A. (2018).

Pengaruh Dukungan Sosial Terhadap Kesehatan.

Awan, I., \& Sodik, M. A. (2018).

Diskriminasi dan Kesehatan Mental.

Siyoto, S., \& Sodik, M. A. (2015). Dasar metodologi penelitian. Literasi Media

Publishing 